\title{
Considering Nursing Theory Certification
}

\section{ABSTRACT}

Objective: A workshop to discuss development of nursing theory certifications at four levels of nursing knowledge was held as part of the 2016 annual conference of Roy Adaptation Association International. Method: Eight questions were discussed in small and large group formats. Discussion points hand recorded on a flip chart. These points are summarized in this article. Results: 35 international nurse scholars participated. They discussed benefits, limitations, and strategies of a new type of certification for nursing theory knowledge at four levels of education and practice. Conclusion: Nursing theory certification would affirm nursing knowledge, without becoming a burden to nurses. It can potentially affect how nurses are educated about theory at each of the four levels of education, how nurses use theory in practice, and the quality of nursing care provided. Continued dialog is warranted.

\section{KEYWORDS}

Nursing theory; certification; models; nursing (Fuente: DeCS).

The topic: Epistemology

Contribution to the discipline: This manuscript contributes a new way to think about the goals of teaching and learning theoretical nursing knowledge at four different levels of formal nursing education. It encourages dialog to develop certification for nursing theory that could promote clinician, faculty, administrator development and collaboration based on mutual nursing theory use.

\section{DOI: 10.5294/aqui.2018.18.2.2}

Para citar este artículo / To reference this article / Para citar este artigo

Hanna DR, Buckner EN. Considering Nursing Theory Certification. Aquichan 2018; 18(2): 139-148. Doi: 10.5294/aqui.2018.18.2.2

$1 \bowtie$ orcid.org. 0000-0001-5100-5256. Hagan School of Nursing, Molloy College, USA. dhanna@molloy.edu

2 orcid.org.0000-0001-9676-2445. Samford University, USA. ellen.buckner@samford.edu 


\section{Considerando la certificación de la teoría de enfermería}

\section{RESUMEN}

Objetivo: se realizó un taller para discutir el desarrollo de las certificaciones teóricas de enfermería en cuatro niveles de conocimiento de enfermería como parte de la conferencia anual de 2016 de la Roy Adaptation Association International. Método: se discutieron ocho preguntas en formatos de grupos pequeños y grandes. Los puntos de discusión fueron grabados a mano en un rotafolio. Estos puntos se resumen en este artículo. Resultados: 35 académicos internacionales de enfermería participaron. Discutieron los beneficios, las limitaciones y las estrategias de un nuevo tipo de certificación para el conocimiento de la teoría de enfermería en cuatro niveles de educación y práctica. Conclusión: la certificación de la teoría de enfermería confirmaría el conocimiento de enfermería, sin convertirse en una carga para las enfermeras. Puede afectar potencialmente cómo se educa a las enfermeras sobre la teoría en cada uno de los cuatro niveles de educación, cómo las enfermeras usan la teoría en la práctica, y la calidad de la atención de enfermería brindada. Hay una necesidad de un diálogo continuo al respecto.

\section{PALABRAS CLAVE}

Teoría de la enfermería; certificación; modelos de enfermería (Fuente: DeCS). 


\section{Considerações acerca da certificação da teoria da enfermagem}

\section{RESUMO}

Objetivo: realizou-se uma oficina para discutir o desenvolvimento das certificações teóricas de enfermagem em quatro níveis de conhecimento de enfermagem como parte da conferência anual de 2016 da Roy Adaptation Association International. Materiais e método: discutiram-se oito perguntas em grupos pequenos e grandes. Os pontos de discussão foram escritos num quadro tipo flipchart. Esses pontos foram resumidos neste artigo. Resultados: 35 acadêmicos internacionais de enfermagem participaram. Discutiram os benefícios, limitações e estratégias de um novo tipo de certificação para o conhecimento da teoria da enfermagem em quatro níveis de educação e prática. Conclusão: a certificação da teoria da enfermagem confirmaria o conhecimento de enfermagem sem se tornar uma carga para os enfermeiros. Pode afetar potencialmente como se educam os enfermeiros sobre a teoria em cada um dos quatro níveis de educação, como esses profissionais usam a teoria na prática e a qualidade da atenção de enfermagem oferecida. Há necessidade de dialogar continuamente a respeito do tema.

\section{PALAVRAS-CHAVE}

Teoria da enfermagem; certificação; modelos de enfermagem (Fonte: DeCS). 
A question was posed at the end of the 2015 annual conference of the Roy Adaptation Association International (RAA-I) (1): Where should the scholarly work in nursing theory go next? One idea was to develop a certification credential for nursing theory. After the conference, that idea was considered carefully. Several thoughts emerged that became a formal effort to invite disciplinary discussion about ways to develop nursing theory certification.-Documents related to different types of nursing knowledge were consulted, as were Styles' ideas about certification and accreditation. A workshop entitled "Levels of Theory Knowledge: Implications for Education and Practice" was conducted twice: on June 10, 2016 at the 2016 RAA-I conference (2). In this article, the workshop conversations are summarized and reported. A total of 35 nurse scholars from six countries (Panama, Colombia, Mexico, El Salvador, Japan, and the United States) participated in the workshops. Many attendees at the workshops have developed their scholarship using the Roy Adaptation Model. However, the workshop was not aimed specifically at developing certification in the Roy Adaptation Model or for the Roy Adaptation Association International. It was aimed at identifying differences among the four levels of nursing education, practice, and knowledge, as well as clarifying the expectations for teaching and using theory at each of those four levels of education and practice (See Table 1 at p. 147). Eight questions about the value of certification of nursing theory knowledge at the four levels of nursing education and practice were discussed by those who took part in the workshop (See Table 2 at p. 147). The purpose of this article is to present a summary of those workshop conversations.

\section{Background}

Before developing the workshop content, the leaders consulted original writings by Margaretta Styles regarding certification to grasp foundational ideas related to certification, accreditation, regulation, and quality of care as it relates to nurses' knowledge. In addition, core curricula content and principles developed by the American Association for Colleges of Nursing (AACN) for baccalaureate, graduate, and two types of doctoral programs were used to further refine the eight questions to be discussed at the conference (3-6). From these documents, the expectations for how nursing theory would be used at each level of formal education were extracted. (See Table 1) To develop a common understanding among attendees with regard to the eight questions posed at the workshop, a brief introduction was provided by the workshop leaders that related the four levels of formal nursing education to four levels of nursing practice.
Basic education was defined as the level of formal education that leads to the first nursing license. Although several types of basic nursing education still exist, to simplify the workshop discussions, the baccalaureate degree was used to represent the basic level of education. This means that, although students who complete a diploma or associate degree program are eligible to take a nursing license exam in the United States, those forms of basic nursing education were not considered in this discussion. According to the AACN, graduates of basic nursing education programs should be able to read, understand and use theory in clinical practice (3). After completing the basic level of education, most newly licensed nurses enter clinical practice as nurses at a basic practice level. The expectation for nursing theory use in the clinical setting also relates to what is asked of new employees by employers. Depending on an institution's mission and goals, new nurses might be asked to use a single nursing theory selected by nurse administrators for the entire institution.

Graduate nursing education, the second level, builds upon the content of basic nursing education. This second level adds necessary specialty-role-based coursework for advanced practice nursing and leadership roles (4). After completing a master's degree in nursing, graduates should be able to use nursing and non-nursing theories for specialty-based advanced clinical practice, and for leadership roles in administration, education, and research. They should be able to use conceptual models and middle range theories. The expectation is that master's prepared nurses would be able to select and use a variety of grand and middle-range theories to explain and problem-solve work-related situations. However, as Smith and McCarthy have pointed out, the 2011 AACN master's curriculum document reduced its stress on nursing-specific theories, while emphasizing knowledge from other disciplines (7). Their point is that formal nursing education no longer accentuates the focus of the discipline of nursing, since it emphasizes theoretical knowledge from other disciplines, such as medicine, pharmacology, and psychology, more than nursing-specific theoretical knowledge (7). A similar claim about the movement away from nursing knowledge has been made by others (8-10).

Doctoral education is available along two lines: a Doctor of Nursing Practice (DNP) degree (5), also called a practice doctorate, and a Doctor of Philosophy (PhD) degree, also known as a research doctorate (6). Although the DNP and PhD degrees share several kinds of content, neither builds upon the other, since neither doctoral degree is required before obtaining the 
other, if both doctoral degrees are pursued. An advanced practice nurse or nurse leader with a DNP degree is expected to: 1 ) translate published research into practice, so nurses can use it, and 2) conduct secondary research for evidence-based practice from primary studies found in the literature (5). During the workshop, this level of practice based on the DNP was called Translational Advanced Practice Nursing. The DNP curriculum, as stated by the AACN. does not require a greater depth of nursing theory knowledge than education at the master's level.

In contrast, nurses who earn a $\mathrm{PhD}$ degree; that is, a research doctorate, are expected to: 1) design and conduct primary research; 2) use their own primary research to test nursing theory; 3) develop new theory using philosophical knowledge and theorybuilding skills; 4) translate existing and newly developed nursing theory for use in clinical practice, education, administration, or research; and 5) combine primary and secondary research strategies to develop new nursing knowledge (6). During the workshop, this level of practice based on a $\mathrm{PhD}$ degree was referred to as Knowledge Development Nursing Practice.

One implication of these four levels of education is that each time a nurse returns for additional formal schooling that next level of education probably would be matched by the student's ongoing development in terms of personal maturity and professional growth. Nurses who return for formal education at different times would combine personal/professional maturity with higher levels of education. The effect could be a more complex, highly refined contribution at each new level of nursing practice. Although the four levels of formal nursing education and levels of practice can be differentiated, the discipline has not developed clear standards for differentiating the depth and breadth of nursing theory to be taught at each level.

\section{Workshop Strategy}

The workshop presenters briefly gave background information about why this question of certification in nursing theory was raised, and how nursing theory is included in the AACN recommended curriculums for nursing education at the four levels of practice/education: 1) basic practice/baccalaureate, 2) advanced practice/master's, 3) translational practice/Doctor of Nursing Practice, and 4) knowledge development practice/PhD program levels. Participants worked in small groups to discuss two assigned questions. Each small group reported a summary of its discussion on each question to the larger group, followed by a large group discussion of each question. The workshops were not considered research, but were viewed as working conversations among like-minded nurse colleagues interested in advancing nursing theory and nursing knowledge. Many participants were academic nurse scholars (faculty), and a smaller portion of the attendees (approximately 15\%) was comprised of either clinicians or doctoral students interested in nursing theory. All eight questions were not discussed equally, and the conversation flowed with the interest of those present.

\section{Discussion Points}

Discussion of the first question led to new questions about what counts as theory to be certified. Although many people agreed that certification of nursing theory knowledge could raise the standards for teaching, learning, and using nursing theory, some questioned the need for certification of nursing theory at all. Several excellent points were raised about the purpose, process, and effect of certification of nursing theory knowledge within discussions of each of the eight questions. For example, should certification be for all kinds of theoretical knowledge that nurses learn and need, or should certification be only for the knowledge of nursing-specific theories, such as those developed by Nightingale, Roy or Rogers, to name a few? Another point was that nurses learn role-related theories during graduate education, such as educational theories for nurse educators or leadership theories for nurse administrators, in addition to nursing theories. Some participants considered these non-nursing rolerelated theories as necessary for leadership and advanced practice nursing roles. The new question raised by participants was: Are all kinds of theoretical knowledge to be certified or should only nursing theory be certified? The idea behind the question was that nursing theories and non-nursing theories have nothing to do with each other. This point reinforces a common misunderstanding that nurses do not need nursing theory as much as they need theory of pathophysiology or pharmacology. This misunderstanding and concern have arisen due to the new emphasis in the AACN master's curriculum document that has severely curtailed the emphasis on nursing theory, with greatly increased emphasis on non-nursing theories (4).

Some participants questioned the need for certification of nursing theory, viewing certification only as a test to be taken periodically that would add a layer of regulatory burden upon nurses. 
The workshop leaders encouraged participants to think of certification as an affirmation of mastery of knowledge of the discipline. Strategies to achieve nursing theory certification without adding a regulatory burden will be addressed in the discussion section.

The second question of how to differentiate teaching of nursing theory at different levels of formal education needs additional thought and discussion within the discipline. A few nursing professors from Panama and Colombia said they have been in conversations in South \& Central America to develop standards for teaching nursing theory. Nurse scholars in North America have not yet had this conversation, as evidenced by the way nursing theory has been included in the AACN documents for education at the baccalaureate and master's levels $(3,4)$.

Since discussion was intense for several questions, the third, fourth, and fifth questions regarding standards, criteria, and scope were not discussed as well as they might have been. Question number six regarding cultural assumptions elicited another question posed by participants: What criteria could be established that would apply around the world, given that other countries and regions have very different health care systems? Participants agreed that specific content may change in a program, but principles are not changed until there is evidence to disprove one set of principles and to adopt a set of new ones. Therefore, it seemed possible to develop general standards that could apply worldwide, but would not impede any culture or country from adopting more stringent ones.

The final workshop questions addressed the points of whether the final independent doctoral work for DNP and PhD programs (a capstone project or dissertation) could qualify for certification at the doctoral level of education, and whether such certification at the doctoral level, once earned, could be kept for life, or if periodic re-evaluation would be needed. Participants discussed whether the inclusion of nursing theory in a capstone project at the end of the DNP level of education or a doctoral dissertation at the end of PhD level education would qualify as sufficient evidence of scholarly work to warrant certification at the doctoral level. This discussion included points regarding the depth, breadth, and sophistication of how nursing theory had been included in capstone projects or dissertations. If the work for a capstone project or a dissertation could be compared to standards for mastery of nursing theory, then such work could be accepted as a portfolio contribution toward certification at the translational level of practice or at the knowledge development level of practice. Portfolio certification, if achieved at this level, would be retained for life, since the investment of time, effort and thought would be a transformative experience. At the completion of either doctoral program (DNP/PhD), graduates practice as independent scholars at the level related to the doctoral degree earned. This explains why theory certification at the doctoral level differs from theory certification at the baccalaureate and master's levels.

Since formal education at the four different levels produces increasing depth of understanding of theory, it seems that basic and master's education could be tested at least once, with the initial licensing exam and with the first advanced certification exam to demonstrate mastery at each level. For example, a sub-score for the specific portion of the licensing exam that relates to nursing theory could be generated with the final test score. In-depth theoretical knowledge could be tested periodically with repeated advanced practice certification exams, but once a nurse progresses from basic to advanced level practice with a master's degree, there would be no further need to test at the basic level. The test at the master's level should supersede the test at the basic level. Likewise, once a doctoral student has engaged in using nursing theory for either a capstone project or a doctoral dissertation, then the project or dissertation could be certified as a lifetime achievement if it meets the criteria for mastery of that theory. Some workshop participants still thought continued review was essential, but it was not agreed that all levels of knowledge and practice would be treated in the same manner with a separate, periodic test. Methods of demonstrating mastery could also include portfolios, published writing, and continued research using that theory or any other nursing theory.

\section{Discussion}

At all levels of practice, nurses are required to hold an active, unimpeded license to engage in professional nursing. Nurses are not required to be certified at the basic level of practice. Certification of nursing knowledge has long been associated in nursing with affirmation of the mastery of either specialty-based or role-related knowledge. Therefore, it has been linked to graduate education and the use of knowledge for advanced practice and leadership roles. Certification in specialty-based knowledge also has been tied to an affirmation of the content of basic practice in a clinical specialty such as critical care or oncology nursing, among others. Licensing exams provide the credential needed for admis- 
sion to basic professional practice. Licensing exams affirm that the student has attained the minimal disciplinary knowledge required to provide professional nursing care safely. Achieving certification of basic theoretical nursing knowledge at the same time as taking the licensing exam for one's first license could seem like a burden to new nurses. However, certification of theoretical nursing knowledge could be accomplished during licensing exams if the exam included a subset score for items about nursing theory. If passing the license exam requires a certain percent of correct items, and if certification of basic knowledge requires a higher percentage of correct items the subset of theory items, then someone who passes the license exam with very high marks in general content and in nursing theory items could show distinction by obtaining a license and a basic theory certification credential at the same time, with a single test. Such a certification derived from the basic licensing exam would help employers who seek nurses who are knowledgeable, even if they are inexperienced.

Since a former expectation for accreditation was that nursing programs should be developed according to a conceptual model or grand nursing theory, some nursing schools and faculty have continued using this approach to nursing education. However, due to revised documents from the AACN, emphasis has shifted to the non-nursing theories more strongly recommended in the AACN documents. Smith and McCarthy have noted that this shift in emphasis has placed the focus of the discipline of nursing at risk for future generations of students (8).

\section{Magnet ${ }^{\circledR}$ Recognition and the Link to Nursing Theory in Clinical Practice}

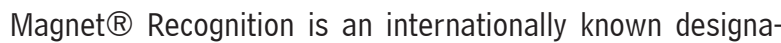
tion of excellence for hospitals and health systems (11). To obtain Magnet $\AA$ Recognition, hospitals are required to show evidence of exemplary clinical practice that is based on a nursing theory (12). This requirement has given new life to the use of nursing theory in clinical settings. When this point was raised by participants during the workshop discussions, it became clear that nursing theory can be a bridge to strengthen the practice-to-academic education relationship. One point from the workshop conversations was that a practice-to-academic education gap has replaced the long-held idea of a theory-to-practice gap. In an era with increased academic-practice collaborations, nursing theory can provide a common language for clinicians and educators. It could strengthen collaborative partnerships. Certification in nursing theory knowledge for staff nurses and leadership nurses could strengthen hiring practices in clinical areas, and could strengthen the evidence needed for Magnet Recognition. This echoes the AACN recommendation for strengthening collaboration between academic health centers and faculty in schools of nursing, as outlined in the 2016 report entitled Advancing Healthcare Transformation: A New Era for Academic Nursing (13).

\section{Teaching Nursing Theory Across the Curriculum}

As faculty seek new strategies for teaching nursing theory, exemplars from practice linked to nursing theory are essential in clinical experiences and simulation laboratories. Undergraduate nursing education prepares the practice-based, frontline nurse who provides care for individuals, families, groups, communities, and populations (3). Critical to that role is an understanding of the theoretical ideas that define nursing. Nursing's unique body of knowledge has a substantive theory base evident throughout the historical development of the profession. From Nightingale's time to the present day, nurses have used observation, compassion, presence, and empathy to provide and coordinate care. Students want to learn the nursing perspective that makes nursing a unique profession (7).

Advanced practice roles require nursing theory use. Graduate education programs intentionally incorporate nursing theory into advanced practice clinical expectations and final capstone projects. Some nursing programs now focus on baccalaureate to DNP degrees, or baccalaureate to PhD degrees, with theory-guided practice and research as essential theoretical underpinnings and core educational components (4). Cody stated that nurses have an obligation to apply the specific knowledge base of the discipline, to contribute to its development, and to evaluate its use by peers and colleagues (14). He differentiated generic or non-nursing theory used in nursing, for example, pharmacology or nutrition, or specialty concepts such as health promotion, from nursing theory built upon a well-articulated philosophy of nursing. Nurses' values guide practice and provide meaning to nursing care. Nursing will only develop as a scholarly discipline to the extent that nursing theory guides it. Considering the need for a common nursing theory base, it is important to contemplate what is needed to assure transfer and expansion of nursing knowledge 
globally and to future generations. Nursing theory certification at the four different levels of a nurse's career could guide that muchneeded foundation.

\section{Approaches to Reducing the Regulatory Burden and Brainstorming Certification Strategies}

Certification can be accomplished in many other ways than by means of a periodic exam. If nursing theory certification could be merged with other required licensing and certification processes that already exist, certification would not become a burden. For example, could a subset score about theoretical thinking ability be derived from future basic licensing exams that might make those nurses who have a good score in theoretical thinking more appealing to hire or more likely to succeed in graduate and doctoral studies? Latin American and South American participants explained that, in their countries, the national exam to become licensed already includes testing of nursing theory. The same is true of the NCLEX licensing exam in the United States. Although aggregate scores and sub-scores for graduates of nursing programs can be analyzed according to the test blueprint, those sub-scores are not currently provided to individual nurses. Only the final status of pass/fail is provided.

Participants agreed that standards for teaching and learning nursing theory should be standardized worldwide. Some suggested a basic level and advanced level of teaching standards with increasing breadth, depth, and evident use of theory-based knowledge from basic to advanced levels.

At present, the blueprints for advanced practice nursing certification exams in the United States require knowledge of several nursing theories. However, the items for nursing theory are not reported as a separate score. If a sub-score regarding theoretical thinking could be generated from the exam, this would present a chance for certification of advanced practice knowledge of nur- sing theory that would not add a burden for a separate nursing theory certification. The first license exam usually is passed one time, but advanced practice certification is accomplished approximately every five years for many certifications. Re-certification can be accomplished without a new test, through a combination of practice hours and continuing education hours. If some of the continuing education could come from nursing theory activities, a separate certification in nursing theory could be maintained. Once someone has progressed from basic to advanced practice, then it seems that certification at the basic level is no longer needed. Likewise, once someone has progressed from the advanced practice level to either the translational practice or knowledge development level, then certification at the advanced practice level would no longer be needed.

\section{Conclusion and Next Steps}

The pursuit of evidence-based practice has provided an incentive to some within nursing for the continued development and use of nursing knowledge. Just when theoretical thinking is needed to guide this pursuit, curriculum guidelines have deemphasized it. Based on the discussion of the participants in this international theory-focused workshop, there is an opportunity to collaborate by starting an engaged international dialog. Nurses from practice, education, and research can discuss strategies for nursing theory certification that are not a burden, as well as the educational content about nursing theory for each level of practice, and, lastly, who will be responsible for affirming certification at each level. Nursing theory certification is one way to affirm nursing theory knowledge for the benefit of nursing as a discipline. However, the purpose of professional certification is to benefit patients by certifying knowledge that supports safe patient care. The goal of this work is not simply to initiate a dialog but, more importantly, to create authentic, thoughtful discussion of nursing knowledge at all levels and to ensure that nurses will preserve the focus of our discipline at all levels of education and in all forms of nursing practice.

Conflict of Interest: None was declared. 
Table 1. Four levels of nursing education and corresponding levels of practice

\begin{tabular}{|c|c|c|}
\hline $\begin{array}{l}\text { Levels of nursing } \\
\text { education attained }\end{array}$ & Levels of nursing practice & $\begin{array}{l}\text { Expectations for each level of nursing knowledge as it is used in } \\
\text { practice }\end{array}$ \\
\hline Undergraduate & Basic practice & Reads, understands, and uses nursing theory in clinical practice \\
\hline Graduate & $\begin{array}{l}\text { Advanced practice } \\
\text { [builds on basic practice] }\end{array}$ & $\begin{array}{l}\text { Uses many theories in practice including middle range, conceptual mo- } \\
\text { dels, and role-related theories [education, administration, leadership] }\end{array}$ \\
\hline $\begin{array}{l}\text { Doctoral (DNP) } \\
\text { (practice doctorate) }\end{array}$ & $\begin{array}{l}\text { Translational p } \\
\text { [builds on adva }\end{array}$ & $\begin{array}{l}\text { Translates published research into practice; conducts secondary re- } \\
\text { search. Theory use expectation is the same as APRN level of practice }\end{array}$ \\
\hline $\begin{array}{l}\text { Doctoral (PhD) } \\
\text { (research doctorate) }\end{array}$ & $\begin{array}{l}\text { Knowledge development practice } \\
\text { [Builds on basic and advanced } \\
\text { practice] }\end{array}$ & $\begin{array}{l}\text { Develops new theory; tests existing theories; translates theory for use in } \\
\text { education, administration, practice, and research; designs and conducts } \\
\text { primary research to produce new knowledge; combines primary and se- } \\
\text { condary research strategies to develop new knowledge. }\end{array}$ \\
\hline
\end{tabular}

Source: American Association of Colleges of Nursing.

Table 2. Eight questions for workshop small-group discussion

1. Would it be worthwhile to establish a structure for certification of theoretical nursing knowledge at four levels? If so, what criteria should be used for each level?

2. If we define the relationship between theory and practice for each level of education, how should teaching theory be differentiated so that each level of education builds upon the others?

3. What standards for teaching theory at each level should be established to ensure that it is being taught in an accurate, useful, and practical way?

4. Could the discipline of nursing develop standards to determine who would be certified in theory or not certified? If so, at which levels should nurses be certified?

5. Which criteria would be best suited to determine the scope of expertise in theoretical nursing knowledge for each level?

6. Where we have cultural assumptions working in certain cultures, how will the criteria accommodate those differences?

7. At the DNP and PhD levels, would the conduct of a capstone project or a primary research study qualify as sufficient for certification at those levels?

8. Would certification in nursing theory be earned once and kept for life, or would it need periodic updates? 


\section{References}

1. Global perspective of the Roy Adaptation Model-Countries and cultures. Annual Conference of the Roy Adaptation Association-International; 2015 June 12-13; Chestnut Hill, MA, USA.

2. Hanna DR, Buckner EB. Levels of theory knowledge: Implications for education and practice. Workshop conducted at: Roadmap for the Next 25 Years: Knowledge Based on the Roy Adaptation Model. Annual Conference of the Roy Adaptation Association-International; 2016 June 10-11; Chestnut Hill, MA, USA.

3. American Association of Colleges of Nursing. The essentials of baccalaureate education for professional nursing practice. Washington DC: American Association of Colleges of Nursing; 2008.

4. American Association of Colleges of Nursing. The essentials of master's education in nursing. Washington DC: American Association of Colleges of Nursing; 2011.

5. American Association of Colleges of Nursing. The essentials of doctoral education for advanced nursing practice. Washington DC: American Association of Colleges of Nursing; 2006.

6. American Association of Colleges of Nursing. The research-focused doctoral program in nursing: Pathways to excellence. Report from the AACN task force on the research-focused doctorate in nursing; 2010. Retrieved from http://www. aacn.nche.edu/education-resources/PhDPosition.pdf

7. Smith M, McCarthy MP. Disciplinary knowledge in nursing education: Going beyond the blueprints. Nurs Outlook 2010; 58: 44-51. doi: 10.1016/j.outlook.2009.09.002

8. Grace P, Willis D, Roy C, Jones DA. Profession at the crossroads: A dialog concerning the preparation of nurse scholars and leaders. Nurs Outlook 2016;64(1):61-70. https://doi.org/10.1016/j.outlook.2015.10.002

9. Barrett EAM. Again, What is nursing science? Nurs Sci Quarterly 2017;30(2):129-133. DOI: 10.1177/0894318417693313

10. Donohue-Porter P, Forbes MO, White JH, Bauman S. Transforming nursing education and the formation of students: Using the human becoming paradigm. Nurs Sci Quarterly 2017;30(2):134-142. DOI: 1.101177/0894318417693287

11. American Nurses Credentialing Center. Magnet model: Exemplary professional practice. 2016; Retrieved from http:// www.nursecredentialing.org/Magnet/ProgramOverview/New-Magnet-Model\#ExemplaryProfessionalPractice.

12. ANCC Magnet Recognition Program. (n.d.). Retrieved June 28, 2017 from http://www.nursecredentialing.org/Magnet

13. American Association of Colleges of Nursing. Advancing healthcare transformation: A new era for academic nursing. American Association of Colleges of Nursing: Washington, DC; 2016.

14. Cody, WK. Nursing theory-guided practice: What it is and what it is not. In Cody, WK (Ed.), Philosophical and theoretical perspectives for advanced nursing practice (Fifth edition, p. 47-50). Burlington, MA: Jones \& Bartlett Learning; 2011. 